\title{
PEMANFAATAN GOOGLE CLASSROOM SEBAGAI MEDIA PEMBELAJARAN ONLINE DI UNIVERSITAS DIAN NUSWANTORO
}

\author{
Swita Amallia Hapsari, Heri Pamungkas \\ Universitas Dian Nuswantoro, Semarang. \\ swita.amallia.hapsari@dsn.dinus.ac.id \\ Diajukan: 22-10-2019; Direview: 29-10-2019; Diterima: 22-12-2019;
}

\begin{abstract}
Nowadays, internet literation become the most important role to develop in our basis life. Therefore, education sector use the information technology for teaching-learning at campus. Google Classroom, is free access facilitate to the lecturer and as e-learning process. Furthermore, this platform offer a lot of advantages for the user. In addition, this platform known as the user friendly tools by smartphone or laptop, create the same opportunities to all the student and make encouragement for student to study more about internet literacy. The research use interpretive paradigm, with qualitative approach and case study method to find the utilization of Google Classroom by the lecturer in Dian Nuswantoro University in major Communication Science Departement, especially for Pengolahan Konten Digital Class. The role of new media in education sector generate the process and make it easily to perform and show that the result need the blended learning to complete and communicate well in the digital era.
\end{abstract}

Keywords: Google Classroom, New Media, Media Internet Literacy

\begin{abstract}
Abstrak
Saat ini, literasi internet menjadi peran yang sangat penting untuk dikembangkan dalam kehidupan dasar kita. Oleh karena itu, sektor pendidikan perlu menggunakan teknologi informasi dalam proses pembelajaran di kampus. Google Classroom, adalah salahsatu akses gratis yang memudahkan dosen dalam proses e-learning. Lebih jauh, platform ini menawarkan banyak sekali keuntungan bagi penggunanya. Selain itu, platform ini dikenal sebagai alat yang mudah digunakan oleh pengguna smartphone atau laptop, serta mampu menciptakan peluang yang sama bagi semua siswa dan mendorong siswa untuk belajar lebih banyak tentang literasi internet. Penelitian ini menggunakan paradigma interpretif, dengan pendekatan kualitatif dan metode studi kasus untuk menemukan pemanfaatan Google Classroom oleh dosen Universitas Dian Nuswantoro khususnya di departemen Ilmu Komunikasi, pada kelas Pengolahan Konten Digital. Peran media baru di sektor pendidikan ini menghasilkan proses yang begitu mudah untuk dilakukan dan menunjukan bahwa hasil penyelesaiannya membutuhkan program pembelajaran campuran atau blended Learning dalam berkomunikasi yang baik di era digital.
\end{abstract}

Kata Kunci: Google Classroom, Media Baru, Literasi Media Internet

\section{PENDAHULUAN}

$\mathrm{S}$ ebagai salah satu universitas swasta yang terkemuka di kota Semarang, Universitas Dian Nuswantoro memiliki motto memberikan masa depan yang lebih baik kepada seluruh civitas akademik. Dilengkapi dengan visi sebagai universitas yang unggul dalam pendidikan dan kewirausahaan serta misi menciptakan mahasiswa berkualitas dan mampu mengembangkan kreativitas, inovasi serta berkontribusi dalam sosial, pemerintahan dan sektor bisnis. Untuk mencetak mahasiswa yang berkualitas, unggul serta kreatif dan inovatif maka banyak upaya yang dilakukan. Salah satunya mendorong mahasiswa untuk terliterasi mengenai media internet.

Era teknologi 4.0 mewajibkan mahasiswa yang nantinya akan terjun ke industri dan siap dengan media digital yang terus berkembang. Utamanya, mampu mengoptimalisasi media internet yang banyak digunakan sebagai sumber pengetahuan di era teknologi. Kini, dosen atau 
tenaga pengajar tidak lagi dianggap menjadi satusatunya sumber pengetahuan melainkan dilengkapi dengan kehadiran media internet sebagai sumber pengetahuan baru. Namun untuk membuat mahasiswa mampu memilah dengan baik dengan media internet maka perlu diberikan pengetahuan. Hasil penelitian (Reginasari \& Annisa, 2018:186) menyebutkan bahwa tantangan bagi Universitas masa kini adalah menghubungkan literasi digital dalam sistem pendidikan. Dalam hal ini literasi media internet menjadi penting bagi mahasiswa. Media internet yang menyediakan berbagai sarana untuk pembelajaran dapat dimanfaatkan dengan tepat oleh mahasiswa. Penelitian yang dilakukan oleh Deden Sutrisna (Sutrisna, 2018:70) menunjukkan bahwa kemampuan literasi mahasiswa dapat dilihat dari penggunaan media baru, salah satunya Google Classrom. Kemampuan literasi internet ini yang mampu membuat mahasiswa semakin terkoneksi dengan media baru.

Menganalisa kemampuan mahasiswa yang mengenal literasi internet, penelitian (Kurniawati \& Baroroh, 2016:53) mengungkapkan bahwa mahasiswa di era cyber menjadikan media baru sebagai kebutuhan primer, sehingga mahasiswa sangat dekat dengan internet dan memiliki ketergantungan yang tinggi.

Berdasarkan data dari Hootsuite.com, Januari 2019, yang merilis penggunaan internet di Indonesia, total populasi dari 268,2 juta jiwa penduduk yang ada ternyata memiliki jumlah persentase penetrasi pengguna internet hingga 56 persen. Dalam keterangannya, Hootsuite juga menyebutkan bahwa pengguna internet yang ada mengakses aplikasi dengan jumlah mobile subscription sebesar 133 persen. Sementara 150 juta jiwa yang mengakses internet dan menggunakan sosial media dengan jumlah persentase 56 persen. Jika dibandingkan dengan data Hootsuite pada tahun-tahun sebelumnya, peningkatan yang melonjak terjadi pengguna yang mengakses media sosial mengalami kenaikan. Tercatat di tahun 2018 pengguna sosial media memiliki jumlah persentase di angka 39 persen, dengan kenaikan hingga 17 persen di tahun 2019.

Didukung oleh (Surahman, 2016:33) dalam penelitiannya yang mengungkapkan peranan teknologi dalam hal ini internet mampu mengubah penggunanya untuk memiliki cara berpikir yang berbeda serta berperan dalam pembentukan perilaku. Media mampu mengubah cara seseorang.

Memperhatikan data yang tercatat per Januari 2019 dari survey Hootsuite.com, jumlah populasi di Indonesia yang mencapai 268,2 juta jiwa terpenetrasi dengan internet meraih angka 56\%. Artinya, bahwa penggunaan internet sudah dilakukan lebih dari separuh penduduk yang tersebar di seluruh pelosok negeri. Hal ini karena perangkat media digital seperti smartphone yang terkoneksi internet mampu mengakses beragam konten baik teks, gambar dan video.

Keberadaan internet sebagai media dengan tingkat pengguna yang cukup tinggi menjadi faktor bahwa masyarakat Indonesia semakin gemar mengakses berbagai konten melalui media digital. Menurut Green (2010:73) sebagai media baru, internet dianggap memiliki banyak kelebihan. Pertama, mendukung koneksi jaringan untuk world wide web. Kedua, menghubungkan situs resmi dalam koneksi web. Ketiga, membangunkan software dengan sumber yang terbuka atau yang tertutup. Keempat, semua dapat mengakses dengan berbagai latar belakang budaya dan literasi karena komputer dan bahasa yang digunakan sebagai komunikasi adalah bahasa sehari-hari. Kelima, dapat dimanfaatkan dengan email, chat, instant messaging. Keenam, internet juga dapat difungsikan sebagai blog dan situs jejaring sosial. Ketujuh, internet juga banyak dimanfaatkan sebagai hiburan seperti games, komunitas. Kedelapan, memaksimalkan internet sebagai cara komunikasi yang difasilitasi secara digital dan mudah digunakan dalam kehidupan sehari-hari.

Dalam bidang pendidikan, internet beberapa metode pembelajaran sudah mengutamakan dengan pembelajaran online atau e-learning. Hasil penelitian (Sabran \& Sabara, 2014:122) menyebutkan bahwa menggunakan media baru merupakan pemanfaatan yang adaptif karena mampu mengirimkan serangkaian solusi dalam metode belajar mengajar. Dengan demikian, penelitian ini fokus untuk menganalisa penggunaan media baru dalam metode belajar mengajar. Terutama menggunakan salah satu media ajar yang dibuat oleh Google yaitu Google Classroom 
untuk diterapkan dalam kegiatan belajar mengajar di Program Studi Ilmu Komunikasi, Universitas Dian Nuswantoro dengan mata kuliah khusus Pengelolaan Konten Digital.

\section{LITERATUR DAN METODOLOGI}

Meningkatkan Kemampuan Literasi Mahasiswa Menggunakan Google Classroom (Studi pada Mahasiswa Program Studi Pendidikan Bahasa Indonesia di Universitas Majalengka) oleh (Sutrisna, 2018). Penelitian ini menganalisis literasi media internet pada mahasiswa dan pemanfaatan sumber bahan bacaan dengan menggunakan aplikasi google classroom. Dalam penelitian ini menggunakan paradigma interpretif dengan metode penelitian kualitatif dan pendekatan studi kasus. Menurut Cresswell (2015:135-137), riset studi kasus mencakup studi tentang suatu kasus dalam kehidupan nyata, dalam konteks atau setting komtemporer. Beberapa ciri khas dari riset studi kasus mengidentifikasi suatu kasus yang spesifik. Ada beberapa entitas yang jelas yang terjadi pada individu, kelompok kecil, organisasi atau kemitraan. Semakin spesifik tempat dan waktunya maka dapat mengumpulkan informasi lebih akurat dan dengan situasi yang berlangsung.

\section{Media Baru}

Era 4.0 membuat cara berkomunikasi yang berbeda, berbasis daring atau digital menjadi utama. Keberadaan media baru dalam dunia pendidikan juga mengubah cara pandan objektif dan ruang publik. Dalam proses komunikasi mahasiswa dianggap lebih pasif dalam komunikasi langsung. Melainkan aktif dalam mengakses media baru, dalam hal ini media internet. Menurut Baran (2011:4) Media merupakan salah satu saluran yang dapat membuat khalayak mendapatkan informasi. Selain itu memberikan pengaruh yang besar dalam kehidupan sehari-hari. Media juga mampu menjadi komoditas yang bernilai tinggi sehingga membentuk realitas baru pada khalayaknya.

Kehadiran media baru menjadi cara baru menyalurkan berbagai infromasi yang menggabungkan teknologi komunikasi digital dan terhubung melalui jaringan. Menurut McQuil (2006:26) ada dua hal yang termuat dalam media baru yaitu konvergensi dan digitalisasi. Salah satunya adalah media internet. Melalui internet penggabungan antara teks, audio dan video mudah dilakukan. Ada banyak kelebihan dari media baru sehingga berperan besar dalam kehidupan seharihari. Mulai dari memudahkan seseorang untuk memeroleh informasi dengan cepat dan bisa diakses dimanapun, sebagai media untuk melakukan transaksi jual beli, menjadi sarana entertainment hingga sarana pendidikan yang memudahkan proses belajar mengajar.Interaktivitas juga menjadi kekuatan utama dalam media baru terutama media internet. Media baru menjadi alat sebagai pemenuhan berbagai kepentingan khalayak.

Menurut Lister (2009:15) ada beberapa karakteristik media baru dan membuat penggunanya memiliki ketergantungan. Pertama, menawarkan pengalaman baru dalam membaca berkaitan dengan teks, memberikan hiburan dan cara yang berbeda untuk mengonsumsi media. Kedua, interaktivitas mampu menampilkan warna dunia yang lebih berbeda. Ketiga, melalui media baru amak tercipta pula identitas dan hubungan yang baru tanpa batas ruang dan waktu. Keempat, membangun hubungan yang baru antar manusia dengan bantuan teknologi media. Kelima, berbagai sektor seperti budaya industri, ekonomi, pendidikan, dan lainnnya memiliki bentuk baru dalam organisasi yang keseluruhannya diatur dalam undang-undang.

\section{Determinasi Teknologi}

Perkembangan teknologi terus meningkat setiap tahun, bahkan awal mula teknologi yang diciptakan oleh manusia untuk memudahkan pekerjaan membawa dampak perubahan yang besar. Kemudahan yang ditawarkan akhirnya membuat pengguna dimanjakan hingga mengandalkan dalam aktivitas sehari-hari. Marshal Mc Luhan (1994:221) dalam teori Determinasi Teknologi mengungkapkan bahwa eksistensi manusia ditentukan oleh perubahan dalam berkomunikasi. Perkembangan teknologi komunikasi mampu mengubah kebudayaan manusia.

Di era milenial ini semua kehidupan bersinggungan dengan media massa. Mulai dari ruang keluarga, dapur, sekolah, kantor, pertemanan, bahkan agama, semuanya berkaitan dengan media 
massa. Menganalisa teknologi komunikasi yang terus maju dan canggih sesuai dengan pernyataan Griffin (2003:344) bahwa tidak ada satupun yang tak tersentuh oleh teknologi komunikasi.

McLuhan juga menyebutkan bahwa media massa adalah ekstensi atau perpanjangan dari inderawi manusia (extention of man). Media tidak hanya memperpanjang jangkauan terhadap suatu tempat, peristiwa, informasi, tapi juga menjadikan hidup lebih efisien. Lebih dari itu media juga membantu dalam menafsirkan tentang kehidupan.

Namun semakin pesatnya perkembangan teknologi komunikasi ternyata membawa dampak bahwa manusia semakin didominasi oleh teknologi komunikasi yang diciptakannya sendiri. Teknologi komunikasi bukannya dikontrol oleh manusia namun sebaliknya, pengguna akhirnya dikontrol. Media digital menjadi cara berkomunikasi baru dan menjadi bagian penting dalam kehidupan seharihari. Menurut Nasrullah (2014:24-36) selama ini model berkomunikasi berasal dari satu sumber ke satu audiens atau sering disebut one to one. Perubahan terjadi dalam media digital, tidak lagi model one to one melainkan many to many atau few to few. Komunikasi ini terjadi karena adanya bantuan perangkat komputer dan internet. Berikut beberapa fungsi dari media digital, antara lain, Pertama website, Beberapa orang menggunakan website menjadi salah satu alat untuk mencari dan menghubungkan dokumen yang dapat diakses melalui internet. Ada banyak fitur yang disediakan untuk membuat pengguna dengan mudah memilih atau berpindah dengan cepat ke dari satu halaman ke halaman selanjutnya. Kedua email, Sistem jaringan yang memudahkan untuk mengirim dan menerima pesan lewat akses internet. Sering disebut surat elektronik karena mampu membuat penggunanya mengirimkan pesan dalam jumlah dan wilayah yang tidak terbatas. Ketiga blog, Salah satu platform yang menjadikan tulisan-tulisan untuk dipublikasikan. Merupakan kepanjangan dari web blog dan memudahkan pengguna untuk bisa produktif dalam karya tulisan. Keempat Internet, Sistem jaringan komputer yang dapat mengkoneksikan komputer satu dengan yang lainnya dengan sistem yang terstruktur hingga membuat pengguna dapat berkomunikasi dan berinteraksi tanpa ada batasan waktu dan tempat. dan kelima adalah media sosial, Yang merupakan media dalam jaringan untuk memudahkan para penggunanya terhubung antara satu dengan yang lain, berpartisipasi dan berbagi informasi dan mampu membuat jejaring sosial.

\section{Literasi Media Internet}

Secara sederhana literasi dapat diartikan sebagai kemampuan membaca dan menulis. Menurut Sulzby (1986) literasi sendiri diartikan sebagai kebisaaan dalam hal membaca dan menulis. Arti yang lebih luas, literasi juga didefinisikan meliputi keahlian untuk berbahasa seperti keterampilan untuk menyimak, berbicara, membaca hingga menulis.

Dalam hal ini Google Classroom yang memanfaatkan internet menjadi media digital yang diperlukan sebagai literasi media. Ada banyak fitur-fitur yang mampu dimanfaatkan sebagai upaya meningkatkan kemampuan literasi mahasiswa sehingga kualitas pemahaman mahasiswa terhadap bacaan pun meningkat. Setelah mahasiswa ditugaskan untuk membaca, sebagai realisasinya mereka diminta untuk melaporkan hasil bacaan tersebut dalam bentuk tulisan. Tulisan tersebut kemudian dikirimkan melalui aplikasi google classroom. Berikut ini fitur-fitur yang terdapat dalam google classroom yang bisa dimaksimalkan secara efektif oleh dosen sebagai upaya meningkatkan kemampuan literasi mahasiswa.

Salah satu fitur yang akan sering digunakan oleh para pengajar yang menggunakan fasilitas ini adalah Create Assignment. Bertujuan untuk memberikan tugas kepada mahasiswa. Agar meningkatkan kemampuan literasi mahasiswa, dosen bisa memanfaatkan fitur ini dengan cara memberikan tugas baca yang hasilnya harus dilaporkan dalam bentuk tulisan dan dikirimkan kembali melalui google classroom. Sementara fasilitas lain untuk membuat interaksi dalam platform ini adalah memanfaatkan Create Question. Merupakan fitur yang dapat digunakan untuk memberikan pertanyaankepada mahasiswa.Keunggulan fitur ini adalah dapat mengefektifkan perkuliahan karena saat mengunggah jawaban harus sesuai dengan tenggang waktu (due date) yang telah ditentukan oleh dosen. Create assignment adalah fitur yang 
digunakan untuk memberikan tugas kepada mahasiswa.

Untuk menunjang materi yang dapat dibagikan oleh dosen atau pengajar yaitu memanfaatkan fitur Create Material. Sebagai fitur untuk mengirimkan file materi perkuliahan dalam berbagai format, seperti word, power point, pdf dan bentuk file lainnya yang mendukung materi mudah diunduh dan didapatkan. Sebagai fitur yang bisa memudahkan mahasiswa menjadi lebih mudah memahami instruksi maka fitur Create Topic menjadi penting untuk diperhatikan. Create topik adalah fitur yang bisa digunakan untuk membuat topik perkuliahan yang akan dibahas di kelas virtual atau melalui google classroom sehingga mahasiswa bisa berpartisipasi aktif membicarakan materi perkuliaha baik di kelas biasa maupun di kelas google classroom. Apabila mahasiswa masih ingin menggunakan postingan yang sudah ada dan tidak mengulangnya maka fitur Reuse Post menjadi solusi yang digunakan. Selain itu, dosen dapat menambahkan pertanyaan dan mengeditnya, juga dapat langsung dibagikan ke grup kelas yang akan dituju. Dalam praktik penggunaannya, google classroom sangat mudah untuk digunakan kedalam kegiatan pembelajaran. Literatur mencakup teori dan konsep ilmiah yang menjadi sumber acuan penulisan kajian atau penelitian.

\section{TEMUAN DAN DISKUSI}

\section{Mengenal Media Baru}

Media baru merupakan sebuah inovasi teknologi dalam bidang media yang terdiri dari televisi kabel, satelit, teknologi fiber optic dan computer (Croteau 1991:29). istilah media baru diambil untuk menggambarkan munculnya media yang bersifat digital, berjaringan dan terkomputerisasi. Internet menjadi representasi media baru yang sedang berkembang di seluruh dunia dan dalam jaringan internet terdapat beberapa platform yang digunakan untuk berkomunikasi. Menurut Croteau (2013), media baru muncul akibat inovasi teknologi bidang media yang meliputi televisi kabel, satelit, teknologi optic fiber dan komputer. Internet sebagai media yang merepresentasikan media baru begitu berkembang di seluruh dunia. Berdasarkan data yang dilansir dari Global Digital Report 2019, ada sekitar 4, 388 miliar pengguna internet aktif di seluruh dunia. Dalam jaringan internet, ada beberapa platform yang tersedia yang juga digunakan untuk berkomunikasi.

Perkembangan media kini semakin pesat dengan adanya teknologi baru yang ikut mengembangkan media. Hal ini cukup mempengaruhi dalam dunia pendidikan dan kegiatan proses belajar mengajar. Salah satunya menyediakan fasilitas belajar dengan kelas digital, membuat Google Classroom banyak dipilih menjadi media belajarmengajar. Selain mudah diakses dan digunakan, aplikasi ini dapat menjadi ruang berkomunikasi dan berinteraksi antara dosen dan mahasiswa dalam kelas maya. Ada banyak keuntungan yang didapatkan bagi kedua belah pihak,dalam hal ini pengajar dan mahasiswa. Google Classroom yang dijadikan media pembelajaran untuk kelas Pengelolaan Konten Digital di Program Studi Ilmu Komunikasi, Universitas Dian Nuswantoro sebagai upaya meningkatkan kemampuan literasi internet mahasiswa. Dosen memaksimalkan semua fitur yang diberikan dalam aplikasi Google Classroom agar mengakomodir perkuliahan secara maya.

Pengamatan dilakukan kepada empat mahasiswa (Putri Rihmasari, Yohanes De Britto Bimo Tri Wicaksono, Fiky Nur Fadli dan Kamaludin) yang tergabung dan tercatat dalam kelas Pengelolaan Konten Digital di Program Studi Ilmu Komunikasi, Universitas Dian Nuswantoro. Google Classroom mampu menjadi salah satu alternatif cara untuk menciptakan kelas maya namun tetap menghadirkan interaktivitas seluruh mahasiswa. Literasi internet menjadi modal bagi mahasiswa untuk memiliki pandangan bahwa internet dapat dengan maksimal dimanfaatkan terutama dalam proses pembelajaran. Keempat informan dalam wawancara menjawab dengan sepakat mengenai pengenalan media baru yang membutuhkan proses. Informan Putri menjelaskan bahwa saat pertama kali menggunakan Google Classroom maka ada banyak fitur yang tidak serta merta langsung digunakan dengan maksimal. "Tidak ada fitur spesifik yang saya maksimalkan dalam penggunaan Google Classroom karena saya tidak tahu secara detail ada apa saja fitur didalamnya. Waktu penggunaan yang baru dan minim membuat saya belum bisa memaksimalkan salah satu fitur Google Classroom, perlu adanya pengarahan dan 
sosialisasi agar bisa digunakan secara maksimal”. Jawaban yang diberikan oleh Putri juga senada dengan tiga informan lainnya. Salah satunya Bimo yang mengungkapkan hanya menggunakan fitur yang tampak dan mudah dikenali. "Fitur yang saya maksimalkan dalam penggunaan Google Classroom adalah: fitur forum, karena didalam fitur tersebut banyak terjadi interaksi dari para anggota. Belum mengenal dengan baik maka perlu waktu untuk memaksimalkan,".

\section{Determinasi Teknologi dan Proses Pembelajaran}

Menurut McLuhan (1994:108), teknologi dapat menentukan dan membentuk cara berpikir, berperilaku dari setiap individu dalam bermasyarakat. Dalam artian, bahwa teknologi yang hadir mampu mengubah prilaku dari setiap individu dan akan terus dinamis menyesuaikan kebutuhan. Hasilnya, manusia akan terus bergerak dari abad yang satu ke abad yang lain sesuai dengan teknologi yang tengah hadir.

Berkaitan dengan pemanfaatan teknologi bagi proses pembelajaran dengan teori determinasi ini, manusia belajar dan memiliki cara berpikir saat tengah menggunakan teknologi untuk mengantarkan pesan sehingga membuat proses pembelajaran berlangsung sukses. Empat informan yang menjadi sumber dalam penelitian ini memiliki cara berpikir saat menggunakan teknologi karena sudah terliterasi internet dengan baik.Salah satunya Kamaludin yang mengungkapkan pemahamannya mengenai fungsi intenet sebagai sumber informasi. "Dalam sehari-hari rata-rata waktu yang saya gunakan untuk mengakses internet kurang lebih yaitu 9 jam. Karena saya membutuhkan untuk mengakses sosial media dan membantu pekerjaan sehari-hari. Contoh saat ini adalah saya sedang magang di Telkom Indonesia Regional IV Jateng \& DIY, dimana saya membutuhkan internet untuk mencari referensi dalam membuat poster dan komponennya sehubungan dengan jobdesk unit saya magang. Selain untuk membantu pekerjaan, saya mengakses internet untuk mencari informasi yang saya sukai, contohnya musik, sejarah dan lifestyle." Jawaban yang sama juga diberikan oleh informan Fiky yang menjelaskan peranan internet menjadi kebutuhan sehari-hari untuk mengakses semua informasi. "Penggunaan internet penting bagi saya terutama kemudahan dalam hal menerima pesan komunikasi. Hal terpenting tidak saja untuk memenuhi kebutuhan informasi seputar tugas pekerjaan, namun juga penting dalam hal menerima informasi mengenai tugas perkuliahan,"

Teknologi diartikan sebagai cara untuk mengakomodir segala kebutuhan terutama saat mengerjakan tugas di kelas Pengelolaan Konten Digital. Kehadiran Google Classroom dianggap sebagai pilihan baru untuk mengembangkan keilmuan dengan baik. Dengan bantuan sumber yang informasi tanpa batas, pengguna Google Classroom tetap bisa memaksimalkan perangkat internet dan fasilitas untuk memilih sumber mana yang dapat digunakan. Teknologi memainkan peran dalam kegiatan belajar di Google Classroom sehingga mahasiswa didorong untuk menguasai agar proses pembelajaran berlangsung dengan baik. Bagi mahasiswa yang menggunakan Google Classroom literasi menjadi kegiatan yang tidak dapat terlepaskan saat mengakses tugas dan menyelesaikannya dengan mengolah sumber informasi yang tepat. Namun, ada mahasiswa yang tidak memahami literasi internet sehingga tidak mampu menganalisa informasi yang didapat dengan tepat.

Memaksimalkan penggunaan internet dalam proses pembelajaran disikapi dengan baik oleh mahasiswa dalam kelas Pengelolaan Konten Digital. Dengan paparan teknologi yang terus meningkat, empat narasumber menyatakan mengakses internet dan menggunakan selama lebih dari 6 jam per hari dengan memberikan waktu khusus untuk mengerjakan tugas lebih dari 2 jam melalui akses internet. Sesuai dengan konsep determinasi teknologi bahwa perubahan prilaku indivu dapat terjadi dalam proses belajar mengajar karena teknologi memiliki dampak positif. Keefektivan mengajar dari jarak jauh yang mampu meminimalisir biaya dan waktu, komunikasi yang tanpa batas ruang dan waktu serta dengan mudah memanfaatkan semua fitur yang ada dalam Google Classroom.

\section{Literasi Internet dengan Google Classroom}

Kini, penggunaan internet menjadi bagian yang tidak bisa dilepaskan dari kehidupan bermasyarakat. Data dari APJII (Asosiasi Penyelenggara Jasa 
Internet Indonesia) merilis bahwa sejumlah 171 juta dari 261 juta jiwa jika dipersentase mencapai $64,8 \%$ dengan mengakses internet. Semua aktivitas yang berbasis dengan teknologi internet mampu mengakomodir komunikasi. Internet bisa menjadi cara untuk berkomunikasi, baik mengirim pesan, berdiskusi, berbelanja, hingga belajar. Dalam memenuhi kebutuhan komunikasi ada beberapa perangkat yang biasanya digunakan dan tidak lepas dari aktivitas pengguna Google Classroom, ponsel pintar dan laptop. Beberapa aplikasi yang juga disebut menunjang untuk mengerjakan tugas selain dengan mesin pencari antara lain, Ruang Kerja, Duolingo dan TED.

Google Classroom menjadi teknologi komunikasi paling utama dalam kegiatan proses pembelajaran. Kehebatan teknologi komunikasi ditandai dengan hadirnya metode pembelajaran e-learning. Google Classroom merupakan sarana memperlancar komunikasi jarak jauh antara pengajar dan mahasiswa terutama dalam kelas Pengelolan Konten Digital. Sarana belajar bersama, menerima dan membaca materi, mengirimkan tugas secara jarak jauh hingga menyajikan nilai tugas secara transparansi. Semua mahasiswa yang terlibat dalam proses pembelajaran ini mendapatkan kesempatan yang sama.

Bagi Fiky, informan yang menggunakan Google Classroom ada respons yang diberikan saat diwawancara. "Google Classroom merupakan sarana memperlancar komunikasi jarak jauh antara dosen pengajar dengan mahasiswa, termasuk saya. Manfaat dari Google Classroom dapat menjadi sarana belajar bersama, menerima dan membaca materi bersama, mengirimkan tugas dari jarak jauh, serta dapat melihat langsung nilai tugas yang diberikan oleh dosen pengajar." Dalam keterangannya lebih lanjut Fiky menambahkan bahwa sebagai mahasiswa yang aktif berkegiatan di luar kampus memilih metode belajar mengajar dengan online jadi salah satu solusi agar beberapa pekerjaan dan tugas bisa dilakukan sekaligus karena memanfaatkan teknologi komunikasi. Serupa dengan jawaban yang diberikan oleh informan Putri, "Fleksibilitas waktu dan tempat lebih terasa karena tidak terikat dengan jadwal yang harus bertatap muka, kecuali saat diadakannya konsultasi. Selain itu menjadikan lebih mandiri dalam memahami suatu materi ataupun tugas yang diberikan.”. Sebagai informasi tambahan Putri juga menjelaskan bahwa penggunaan Google Classroom sebagai salah satu solusi media pembelajaran baru mampu membuat kemudahan dalam belajar.

Memanfaatkan Google Classroom sebagai proses pembelajaran dapat membuat mahasiswa sebagai partisipan mampu mengarsipkan tugas dan menghubungkannya dengan penyimpanan Google Drive. Fleksibilitas waktu dan tempat juga membuat Google Classroom menjadi proses pembelajaran yang disukai. Selain menjadikan mahasiswa lebih mandiri juga membuat sesi diskusi layaknya kelas tatap muka tetap dapat terjalin. Kehadiran Google Classroom sebagai salah satu media pembelajaran diminati dan membuat pengalaman baru mahasiswa dalam kelas Pengelolaan Konten Digital.

Walaupun ada beberapa yang belum mengenal Google Classroom sebagai metode pembelajaran yanb baru tetapi kemudahan yang diberikan membuat mahasiswa dengan mudah mengoperasikan. Dengan perilaku yang berubah tidak menggunakan kelas tatap muka melainkan hanya kelas maya maka ada beberapa hal yang terjadi. Perubahan dari sisi fleksibilitas waktu dan tempat. Kontribusinya juga terhadap lingkungan karena mengurangi tumpukan kertas dan menyelamatkan bumi. Mahasiswa yang aktif dapat membuat proses pembelajaran pun semakin interaktif. Namun tidak semua mahasiswa dapat menjadi partisipan aktif karena dalam kelas maya atau digital tidak ada keharusan dan kewajiban untuk merespons secara langsung. Hal ini disadari penuh oleh para pengguna Google Classroom untuk proses pembelajaran. Beberapa ingin kelas maya tetap hadir namun dilengkapi dengan kelas tatap muka agar interaksi tetap berjalan dengan baik.

Seperti yang disampaikan informan Kamaludin dalam wawancaranya mengenai kelanjutan untuk menggunakan Google Classroom. Walaupun terhitung baru menggunakan menurutnya media baru ini terbukti menjadikan kebutuhan proses belajar mengajar lebih mudah dan akan terus menggunakan. "Ya, saya berminat untuk terus menggunakan media baru ini. Tetapi menurut saya Google Classrom tidak bisa digunakan sebagai 
media utama dalam kegiatan belajar. Karena interaksi secara langsung (tatap muka) juga tidak kalah penting dalam kegiatan belajar mengajar. Interaksi langsung (tatap muka) juga lebih efektif dalam berjalannya kegiatan belajar karena kita bisa dapat respon secara langsung juga. Penggunaan Google Classroom menurut saya penting dilakukan tetapi hanya sebagai selingan atau pengganti serta perlu ada fitur tambahan untuk menarik minat mahasiswa agar bisa aktif didalam Google Classroom tersebut."

Untuk menggunakan Google Classroom, mahasiswa kelas Pengelolaan Konten Digital selama tiga bulan mendapatkan pengalaman baru dengan kelas maya. Beberapa mendapatkan kemudahan dalam mengumpulkan tugas dan mendapatkan umpan balik atau respons lebih cepat dari dosen pengajar. Menjadi pengingat dengan notifikasi bagi mahasiswa untuk mengerjakan tugas. Selain itu, mampu mengakomodir kelas tetap berlangsung walaupun dosen tidak bisa hadir atau berhalangan datang. Namun kesulitan yang banyak ditemui mulai dari ketergantungan jaringan sinyal, belum terbiasa menggunakan Google Classroom sehingga masih kurang memaksimalkan fitur yang ada. Hilangnya fokus saat mengerjakan tugas karena ada notifikasi. Selanjutnya beberapa fitur yang diinginkan seperti fitur pencarian dan penyimpanan data sementara yang belum terakomodir.

Untuk meningkatkan kemampuan literasi mahasiswa maka Google Classroom menjadi salah satu caranya. Mahasiswa kelas Pengelolan Konten Digital di Program Studi Ilmu Komunikasi, Universitas Dian Nuswantoro banyak yang merespons positif. Sebagai media utama dalam kegiatan belajar masih dipertimbangkan tetapi jika menggabungkan Google Classroom dengan kelas tatap muka sebagai cara untuk memperkuat interaksi antara pengajar dan mahasiswa sebagai partisipan.

Beberapa faktor pendukung proses pembelajaran Google Classroom yang perlu ditingkatkan mulai dari kesiapan pengajar yang mampu memberikan instruksi pembelajaran e-learning dengan baik. Memfasilitasi konsultasi untuk menggunakan Google Classroom supaya maksimal serta memotivasi pembelajaran Google
Classroom agar semakin aktif. Sebagai saran untuk penelitian selajutnya, perlu diujicobakan secara kuantitatif upaya meningkatkan kemampuan literasi mahasiswa dengan menggunakan aplikasi Google Classroom.

\section{SIMPULAN}

Untuk meningkatkan kemampuan literasi mahasiswa maka Google Classroom menjadi salah satu cara untuk memanfaatkan media baru dalam proses kegiatan belajar mengajar. Mahasiswa kelas Pengelolaan Konten Digital di Program Studi Ilmu Komunikasi, Universitas Dian Nuswantoro banyak yang merespons positif. Sebagai media utama dalam kegiatan belajar masih dipertimbangkan tetapi jika menggabungkan Google Classroom dengan kelas tatap muka sebagai cara untuk memperkuat interaksi antara pengajar dan mahasiswa sebagai partisipan. Empat informan yang mewakili sebagai pengguna Google Classroom memiliki simpulan yang sama bahwa memanfaatkan media baru sebagai salah satu cara mempermudah mahasiswa belajar mengajar sangat menjadi nilai yang positif. Terutama waktu yang semakin fleksibel dan membuat beberapa keuntungan lain dapat belajar dimanapun tanpat terbatas hanya saat kelas.

Beberapa fator pendukung proses pembelajaran Google Classroom yang perlu ditingkatkan mulai dari kesiapan pengajar yang mampu memberikan instruksi pembelajaran e-learning dengan baik. Memfasilitasi konsultasi untuk menggunakan Google Classroom supaya maksimal serta memotivasi pembelajaran Google Classroom agar semakin aktif. Sebagai saran untuk penelitian selajutnya, perlu diujicobakan secara kuantitatif upaya meningkatkan kemampuan literasi mahasiswa dengan menggunakan aplikasi Google Classroom. Rekomendasi untuk penelitian selanjutnya, bisa melengkapi penelitian yang dapat menganalisa peran metode pembelajaran blended learning, menggunakan media baru dan media konvensionl.

\section{DAFTAR PUSTAKA}

Anggraini, S. (2016). Budaya Literasi Dalam Komunikasi. Wacana: Jurnal Ilmiah Ilmu Komunikasi, 15(3), 181-279. Retrieved 
from http://journal.moestopo.ac.id/index. $\mathrm{php} /$ wacana/article/view/51

Baran, Stanley. (2011). Pengantar Komunikasi Massa. Jakarta: Salemba Empat

D,Croteau \& W, Hoynes. (2013). Media/Society: Industries, Images and Audience, Sage Publications.

D, Croteau. (1991). A transitional teaching experience : learning groups and the first time teacher. American Sosiological Associations.

Green, Leila. (2010). The Internet: An Introduction to the New Media.

Griffin, Emory A. (2003). A First Look at Communication Theory, 5th Edition, New York: McGraw-Hill.

JW, Crewell. (2015). Qualitative Inquary \& Research Design : Choosing Among Five Approaches, $5^{\text {th }}$ Edition, SAGE

Kurniawati, J., Baroroh, S. (2016). Literasi Media Digital Mahasiswa Universitas Muhammadiyah Bengkulu. Jurnal Komunikator, 8(2), 51-66. Retrieved from http://journal.umy.ac.id/index.php/jkm/ article/view/2069

Kurnia, N. (2005). Perkembangan Teknologi Komunikasi dan Media Baru: Implikasi terhadap Teori Komunikasi. Mediator, 6(2), 291-296. Retrieved from http:// mediator.fikom.unisba.ac.id/index.php/ mediator/article/view/272

Lister, Martin. (2009). New Media Second Edition. New York:Routledge

McLuhan, Marshall. (1994). Understanding Media: The Extension of Man. London:

\section{The MIT Press}

Mc Quail, Denis. (2006). Teori Komunikasi Massa Suatu Pengantar. Alih bahasa oleh Agus Dharma dan Aminudin Ram. Jakarta: Erlangga.

Nasrullah, Rulli. (2014). Teori dan Riset Media Siber (Cybermedia). Jakarta: Prenadamedia.

Nasrullah, Rulli. (2016). Media Sosial (Perspektif Komunikasi, Budaya, dan Sosioteknologi). Bandung : PT Remaja Rosdakarya.

Rianto, Puji. (2016). Media Baru, Visi Khalayak Aktif dan Urgensi Literasi Media. Jurnal Komunikasi, 02(01), 90-96. https://doi. org/10.25008/jkiski.v2i2.108

Sabran, \& Sabara, E. (2014). Keefektifan Google Classroom sebagai media pembelajaran. Diseminasi Hasil Penelitian Melalui Optimalisasi Sinta Dan Hak Kekayaan Intelektual, 122-125.

Surahman, S. (2016). Determinisme Teknologi Komunikasi dan Globalisasi Media Terhadap Seni Budaya Indonesia. Jurnal Rekam, 12(1), 31-42. Retrieved from http://journal.moestopo.ac.id/index.php/ wacana/article/viewFile/51/29

Sutrisna, D. (2018). Meningkatkan Kemampuan Literasi Mahasiswa Menggunakan Google Classroom. FON: Jurnal Pendidikan Bahasa Dan Sastra Indonesia, 13(2), 69-78. https://doi.org/10.25134/fjpbsi. v13i2.1544

Tamburaka, Apriadi. 2013. Literasi Media. Jakarta: Raja Grafindo Persada. 